Pure Appl. Chem., Vol. 82, No. 11, pp. 2137-2156, 2010.

doi:10.1351/PAC-CON-09-11-49

(C) 2010 IUPAC, Publication date (Web): 6 August 2010

\title{
Electrospun materials for energy harvesting, conversion, and storage: A review*
}

\author{
Michael J. Laudenslager ${ }^{1}$, Raymond H. Scheffler ${ }^{1}$, and \\ Wolfgang M. Sigmund ${ }^{1,2, \ddagger}$ \\ ${ }^{1}$ Department of Materials Science and Engineering, University of Florida, \\ Gainesville, FL 32611-6400, USA; ${ }^{2}$ Energy Engineering Department, Hanyang \\ University, Seoul 133-791, Korea
}

\begin{abstract}
Long-length nanofibers are able to form porous networks with high surface-areato-volume ratios, and decrease diffusion lengths. While there are numerous techniques to create nanostructures, electrospinning is the only technique that allows fabrication of nanofibers at long-length scales. These uniquely shaped fibers are applied to several energy-related devices. This review is an in-depth summary of the uses of electrospun fibers in dye-sensitized solar cells (DSSCs), batteries, capacitors, fuel cells, and hydrogen storage devices. Developments in electrospinning technologies to create novel fiber morphologies are also discussed.
\end{abstract}

Keywords: batteries; capacitors; electrospinning; energy storage; fuel cells; hydrogen storage; solar cells.

\section{INTRODUCTION}

Continued depletion of natural resources and population growth create an increasing demand for materials with enhanced properties that enable higher efficiencies in energy conversion, harvesting, and storage devices. These technologies, which include solar cells, fuel cells, batteries, and capacitors, offer the potential to significantly lower energy-related carbon footprints, decrease dependence on fossil fuels, and create new areas for economic growth. A report released by the U.S. Energy Information Administration (EIA) in 2008 indicated that approximately half of the electrical energy in the United States was generated from coal [1]. Only a small portion is generated from renewable resources, which is primarily due to high upfront installation costs and lengthy amortization times. Development of inexpensive materials along with processing methods to create highly efficient devices will assist in the transition to sustainable technologies. Additionally, an economic opportunity exists in creating a renewable infrastructure, if the cost per kilowatt hour of renewable technologies can be brought to a comparable level of existing technologies.

Limiting the energy-related carbon footprint is achievable by harvesting renewable energy and efficiently converting hydrocarbon-based fuels. According to the EIA, petroleum is the greatest source of carbon dioxide emissions. The EIA estimates $71 \%$ of petroleum in the United States is used for transportation [1]. Therefore, by developing efficient energy storage methods, such as batteries and capacitors, small vehicles can run from grid energy, which can be produced more efficiently and cleanly

\footnotetext{
*Paper based on a presentation at the $5^{\text {th }}$ International Symposium on Novel Materials and Their Synthesis (NMS-V) and the $19^{\text {th }}$ International Symposium on Fine Chemistry and Functional Polymers (FCFP-XIX), 18-22 October 2009, Shanghai, China. Other presentations are published in this issue, pp. 1975-2229.

¥Corresponding author
} 
than is possible in current combustion engines. Efficient energy storage is increasingly important when one considers renewable energy sources, where power production is variable throughout the day. With further development, new battery technologies could store energy from peak production times. Secondary batteries, batteries that are rechargeable, are usually limited by charge and discharge rates, which are inherently based on slow chemical reactions. Therefore, secondary batteries cannot fulfil all requirements for electrical energy storage. To compensate, batteries are often coupled with faster processes that are used in capacitors and supercapacitors. These devices are based on movement of electrons and ions, respectively. Capacitors and supercapacitors have a lower energy density for storage; however, these devices allow for high power rates per mass in charging and discharging. This allows for energy recovery from braking vehicles and elevators [2]. Storing energy in chemicals such as hydrogen is another technology under development; however, numerous efficiency challenges remain [3].

Electrospinning is a method that allows fabrication of nanostructured materials with controlled dimensions. Furthermore, it is applicable to a wide range of materials and is currently the only method that can produce continuous fibers with diameters of less than $500 \mathrm{~nm}$ (down to $20 \mathrm{~nm}$ ) with lengths of several meters $[4,5]$. Fibers may be collected as randomly oriented meshes; however, there are several methods available to obtain oriented fibers. Furthermore, a variety of fiber morphologies are possible as is discussed in later sections. This review provides an in-depth discussion of the current state of electrospun materials in energy storage devices. Interested readers are directed to three recent articles that overview applications of electrospun fibers [6-8]. In contrast, this review provides in-depth discussions of electrospun energy materials.

The main reason electrospinning excels as a fabrication method for energy materials is its versatility in transforming a wide range of polymers and ceramics into nanostructures. Therefore, bulk materials that are currently not suitable for their use in energy materials suddenly become desirable due to enhanced performance stemming from quantum-level effects or increased surface-area-to-volume ratios. Reducing grain size in the orders of magnitude opens new paths for electron, ion, and phonon transport. The length scale of the mean free path of these entities is on the order of the nanoscale. Therefore, there is an overall significant advancement predicted when materials move to nanosize dimensions. It is expected that electrospun nanostructures will greatly enhance the performance of devices for these applications.

\section{ELECTROSPINNING OVERVIEW}

Electrohydrodynamic forming methods include electrospraying and electrospinning, which are, respectively, capable of producing nanoparticles and nanofibers from an electrically charged fluid jet. It is possible to destabilize a jet in an electric field into droplets. This electrospraying method allows controlled fabrication of mono-sized particles on the scale of nanometers to microns. The smallest particles reported have a Feret diameter of $5 \mathrm{~nm}$ [9]. The second electrohydrodynamic subcategory, electrospinning, combines higher electric field strength and complex viscous behavior of the electrically charged fluid jet to form fibers. Rayleigh break-up, which is dominated by surface tension and Coulombic repulsion, is overpowered by the entanglement of organic or inorganic polymer chains. The liquid is no longer emitted as droplets, and a thin, continuous fiber is produced.

Electrospinning as a commercial polymer fiber fabrication method has existed since 1934. At that time, Formhals' patent was published in the United States [10]. Researchers limited their focus to the electrospraying of polymers until the start of this millennium. Recent advancements in electrospinning have been aided by a better understanding of the fluid dynamics that give quantitative equations to predict final fiber diameters [11]. These advances led to the development of a wide array of polymer and ceramic nanofibers, which are described in several review papers [4,7,12-14].

Prior to explaining electrospinning theory, a typical laboratory apparatus for electrospinning is discussed. In Fig. 1, an advancement pump moves either a polymer or a ceramic precursor solution through a syringe. A power source attached to the metallic needle charges the liquid droplet that forms 


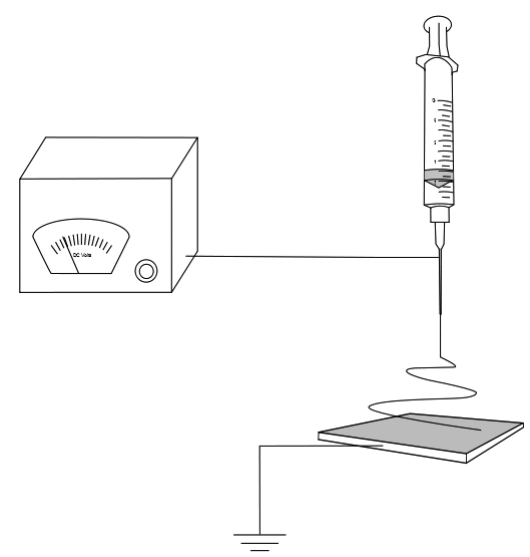

Fig. 1 Simplified lab-scale electrospinning apparatus containing a high-voltage power supply, a syringe with a metallic needle, and a collecting target that is grounded.

at the end of the syringe. The droplet deforms under the electric field and forms a Gilbert-Taylor cone. William Gilbert was the first scientist to report the cone formation of a liquid droplet in an electric field in the $15^{\text {th }}$ century. His findings are published in his book De Magnete [15]. The electrically charged fluid forms a thin jet with an initial diameter of about $1 \mu \mathrm{m}$. The electric field then pulls the fiber toward a grounded target where it is collected. More liquid is pulled through the syringe needle via a combination of capillary forces and the electric field. This unique property of electrospinning reduces the possibility of clogging the spinneret, since it is not an extrusion process. This means that particulate slurries can also be used as precursors, which increases the versatility of the electrospinning process.

The charged liquid jet is ejected at the tip of the Gilbert-Taylor cone and starts to travel toward the target, which has a lower electrostatic potential. Depending on the electric field strength, it will start to bend slightly due to random fluctuations. The first bend causes an additional force to develop due to a charged jet traveling at an angle to the electric field lines. The new force causes increased bending, resulting in a whipping motion that has the ability to thin the fiber diameters from microns to nanometers. Detailed studies with high-speed cameras show that the whipping is actually better described by an expanding spiral motion of a single fiber moving toward a target $[16,17]$. The final fiber diameter is controlled by a force balance of the centripetal force, caused by the electric field interactions with the charges on the jet, and the viscoelastic response of the fiber.

When the viscoelastic responses of the fibers are similar, as is the situation for a number of polymer systems, the final fiber radius can be calculated using Maxwell's equations for a charged fluid jet in an electric field. Fridrikh et al. proposed an analytical model based on these equations [11]. This model allows prediction of the final fiber radius, assuming a single fiber forms from the jet. Under certain conditions, numerous smaller jets branch out from the initial droplet. This phenomenon is further discussed elsewhere [8]. The terminal fiber radius depends on: surface tension $(\gamma)$, dielectric constant of the outside medium $(\varepsilon)$, total current directed toward the lower electrode $(I)$, radius of curvature divided by the diameter of the jet $(\chi)$, and flow rate $(Q)$. Equation 1 shows the relationship between these parameters.

$$
r_{\text {terminal }}=\left(\gamma \varepsilon \frac{Q^{2}}{I^{2}} \frac{2}{\pi(2 \ln \chi-3)}\right)^{\frac{1}{3}}
$$

This formula is independent of the diameter of the needle, droplet size, electric field strength, and dielectric properties of the electrospun materials. The surface charges at the fluid gas interface are key 
to the interaction, and the field strength is accounted for in the current through the fiber. Furthermore, the Gilbert-Taylor cone reshapes any size of droplet or liquid surface, which is dependent on flow rate and electric field strength. Therefore, the starting jet diameter is relatively independent of the spinneret size. Ceramic systems require a more detailed analysis since they have three orders of magnitude higher conductivities. The high conductivity of ceramic precursor systems invalidates the assumptions that are used to develop the parameter $\chi$. However, the equation can still be used for guidance. Interested readers are referred to another article for treatment of ceramic fiber spinning equations that correct for high conductivities, i.e., currents $I$. These equations allow guiding the design of fibers with an accuracy of about $\pm 20 \%$ [13].

It is important to note that not all solutions will form continuous fibers. Equation 1 will predict a fiber radius for any solution regardless of whether that solution will form a fiber at all. Solution properties, electrospinning parameters, and even the power supply itself influence which systems are capable of being electrospun. Non-uniform fibers and beaded fibers are likely to occur with low-molecularweight solutions or low-polymer concentrations, where there is a lack of chain entanglement $[18,19]$. Ceramic systems, which are the most promising for energy applications, require careful attention to solubility limits of polymers in the presence of precursors. In many cases, polymers are salted out of solution or change their conformation, which reduces chain entanglement [20].

Additionally, the higher conductivity of ceramic precursor solutions can prevent the power supply from providing a stable electric field. During electrospinning, ceramic precursor solutions are more highly charged than polymer solutions, i.e., a space charge develops in-between the electrodes that reduce the electric field strength. This causes the power supply to compensate. Depending on the construction of the power supply, it may not be able to adjust properly, which causes the electric field to weaken for several microseconds. This phenomenon may be the reason for observed fluctuations in the final fiber diameter [21].

While electrospun fibers are typically collected as randomly oriented fiber mats, it is possible to orient the fibers by several methods through modifications to the collecting substrate and the electric field and magnetic fields. Most alignment techniques are based on three methods. In the first method, fibers are collected on a cylinder rotated at high speed [22,23]. In the second method, an insulating gap is created in the substrate, which the fibers align across [24,25]. Only a limited number of aligned fibers can be collected via the second method due to interference from the layer of collected fibers [14]. Additionally, there is a limit to the width of the gap, which is dependent on the fiber strength, and hence its diameter. Scanning electron microscopy (SEM) images of fibers collected across a gap are shown in Fig. 2. These images show that the fibers are highly oriented, but are not perfectly aligned. The aligned fibers are easily removed by moving a substrate through the gap. The third method orients fibers by manipulating the electrical or magnetic fields around the electrospun jet [26-28].
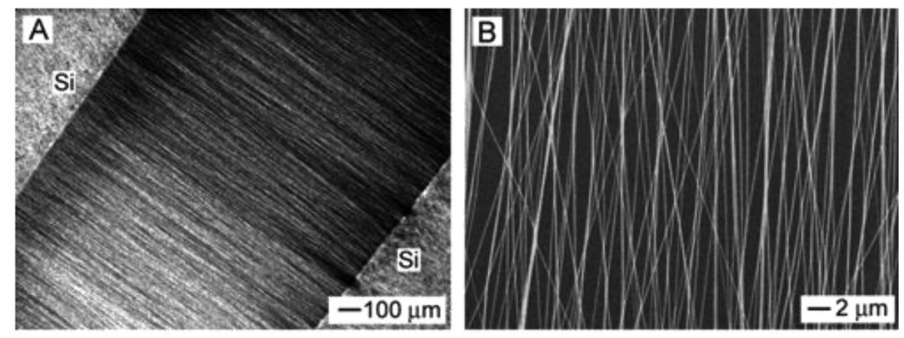

Fig. 2 Aligned electrospun fibers using an air gap method. Reprinted with permission from [25]. Copyright $\odot$ 2004, American Chemical Society. 
Another important advance in the field of electrospinning is the development of core-shell fiber spinning via a two-capillary spinneret. A core-shell fiber-spinning apparatus is shown in Fig. 3. This particular apparatus is made by inserting a small-diameter needle into a larger needle. The end of the inner needle extended slightly past the edge of the larger needle. Different solutions are pumped into each tube, producing core-shell structures in the resulting fibers [29]. This technique is also used to form hollow fibers, by altering the core solution. Hollow fibers are formed by pumping heavy mineral oil as the core solution [30]. The oil is extracted after the fibers are collected, leaving behind a hollow fiber. This technique creates many possibilities for composite and hollow electrospun fibers. The coreshell technique also provides the possibility for electrospinning solutions that are not capable of being electrospun; only one of the solutions needs to be able to carry the charge [29].

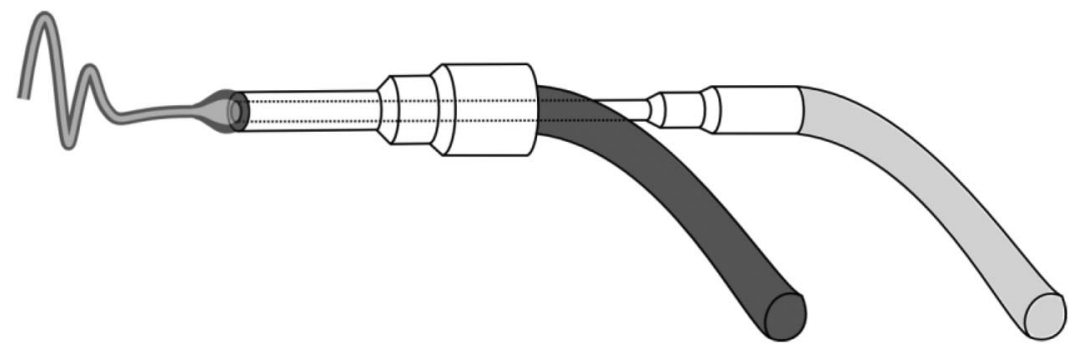

Fig. 3 Core-shell electrospinning device using concentric needles.

\section{ELECTROSPUN ENERGY MATERIALS}

A large number of materials have been electrospun in order to improve energy-related materials. Table 1 summarizes materials that were investigated for various components in energy-related devices using electrospinning. Table 1 is divided into sections based on the material and application: dye-sensitized solar cells (DSSCs), batteries, capacitors, fuel cells, and hydrogen storage. In addition, structural modifications of the materials are noted. The following sections will further elucidate these investigations.

Table 1 Overview of electrospun materials for energy production and storage.

\begin{tabular}{llll}
\hline Application & Component & Material & Ref. \\
\hline DSSCs & Electrode layer & $\mathrm{TiO}_{2}$ & {$[31]$} \\
& & $\mathrm{TiO}_{2}$ single-crystalline nanorods & {$[32]$} \\
& $\mathrm{TiO}_{2}$ multicore fibers & {$[33]$} \\
& $\mathrm{ZnO}$ hot-pressed fibers & {$[34]$} \\
& Mechanically ground $\mathrm{TiO}_{2}$ fibers & {$[35]$} \\
& Nanotubes from PAN template & {$[36]$} \\
\cline { 2 - 4 } & & Poly(vinylidene fluoride-co-hexafluoropropylene) & {$[37]$} \\
\hline
\end{tabular}


Table 1 (Continued).

\begin{tabular}{|c|c|c|c|}
\hline Application & Component & Material & Ref. \\
\hline \multirow[t]{26}{*}{ Batteries } & \multirow[t]{5}{*}{ Anode } & Porous C & [38] \\
\hline & & Sn nanoparticles in PLLA fibers & [39] \\
\hline & & C/Co composite & [40] \\
\hline & & $\mathrm{MnO}$ & [41] \\
\hline & & $\mathrm{Co}_{3} \mathrm{O}_{4}$ & [42] \\
\hline & \multirow[t]{15}{*}{ Cathode } & $\mathrm{PVA} / \mathrm{LiOH}-\mathrm{V}_{2} \mathrm{O}_{5}$ composite membrane fibers & [43] \\
\hline & & $\mathrm{LiCoO}_{2}$ hollow nanofibers & [44] \\
\hline & & $\mathrm{LiNiO}_{2}$ hollow nanofibers & [45] \\
\hline & & $\mathrm{C} / \mathrm{Fe}_{3} \mathrm{O}_{4}$ composite nanofibers & [46] \\
\hline & & $\mathrm{CoO}$ and $\mathrm{Co}_{3} \mathrm{O}_{4}$ & [47] \\
\hline & & $\mathrm{LiNi}_{05}+{ }_{\delta} \mathrm{Mn}_{05}-{ }_{\delta} \mathrm{O}_{2}$ nanofibers & [48] \\
\hline & & Hollow $\mathrm{LiNi}_{0.8} \mathrm{Co}_{0.1} \mathrm{Mn}_{0.1} \mathrm{O}_{2}-\mathrm{MgO}$ coaxial fibers & [49] \\
\hline & & $\mathrm{LiCoO}_{2}-\mathrm{MgO}$ coaxial fibers & [50] \\
\hline & & Spinel $\mathrm{Li}_{4} \mathrm{Ti}_{5} \mathrm{O}_{12}$ & [51] \\
\hline & & $\mathrm{Li}_{1+\alpha} \mathrm{V}_{3} \mathrm{O}_{8}$ nanosheets & [52] \\
\hline & & $\mathrm{LiMn}_{2} \mathrm{O}_{4}$ & [53] \\
\hline & & $\mathrm{P}(\mathrm{VDF}-\mathrm{H} F \mathrm{P})$ membranes & [54] \\
\hline & & P(VDF-HFP)/PMMA & [55] \\
\hline & & PVDF-co-HFP-ZrO 2 & [56] \\
\hline & & Gelled polyimides (Matrimid and Ultem 1000) & [57] \\
\hline & \multirow[t]{6}{*}{ Electrolytes } & $\begin{array}{l}\text { Poly(vinylidene fluoride)-graft-poly(tert-butyl acrylate) } \\
\text { electrolytes }\end{array}$ & [58] \\
\hline & & P(VDF-HFP) with nano-sized ceramic fillers & [59] \\
\hline & & PAN nanofibers & [60] \\
\hline & & Polypyrrole/sulfonated SEBS composite nanofibers & [61] \\
\hline & & $\mathrm{TiO}_{2} / \mathrm{P}(\mathrm{VDF}-\mathrm{HFP})$ hybrid fiber microporous film & [62] \\
\hline & & Activated P(VDF-HFP) & [63] \\
\hline \multirow[t]{2}{*}{ Capacitors } & & Carbonized poly(acrylonitrile) and other polymers & [64-66] \\
\hline & & Ni-embedded carbon nanofibers & [67] \\
\hline \multirow[t]{6}{*}{ Fuel cells } & \multirow[t]{3}{*}{ Catalytic electrode } & $\mathrm{Pt}$ and $\mathrm{Pt} / \mathrm{Rh}$ nanowire electrocatalysts & [68] \\
\hline & & Pt clusters in carbononized fibers & [69] \\
\hline & & Ag-coated polycaprolactone membranes & [70] \\
\hline & \multirow[t]{2}{*}{ Membrane } & Sulfonated poly(ether ether ketone ketone) & [71] \\
\hline & & Nafion-impregnated PVDF & [72] \\
\hline & $\begin{array}{l}\text { Enzyme } \\
\text { immobilization }\end{array}$ & $\begin{array}{l}\text { Polystyrene nanofibers with covalently attached } \\
\alpha \text {-chymotrypsin }\end{array}$ & [73] \\
\hline \multirow[t]{5}{*}{$\begin{array}{l}\text { Hydrogen } \\
\text { storage }\end{array}$} & \multirow[t]{4}{*}{$\begin{array}{l}\text { High-porosity } \\
\text { adsorption layer }\end{array}$} & $\begin{array}{l}\mathrm{Fe}_{3} \mathrm{O}_{4}, \mathrm{MgO}, \mathrm{CuO}, \mathrm{Fe} \text {, and } \mathrm{Mg} \text { catalysts in carbonized PAN } \\
\text { fibers }\end{array}$ & [74] \\
\hline & & Graphite nanofibers from graphitization of PVDF & [75] \\
\hline & & PAN/PMMA-derived $\mathrm{C}$ tubes & [76] \\
\hline & & Fluorinated, carbonized PAN with V & [77] \\
\hline & Electrode & $\begin{array}{l}\text { Carbonized solutions of poly(acrylonitrile) and other polymers } \\
\text { Ni-embedded carbon nanofibers }\end{array}$ & {$[64-66]$} \\
\hline
\end{tabular}




\section{Dye-sensitized solar cells}

Second-generation solar cells, which typically operate at lower efficiencies than traditional Si-based cells, have great potential to increase solar cell cost-effectiveness [78]. Numerous studies have incorporated electrospun fibers into DSSCs, which are a type of second-generation cell. An overview of these studies is presented in Table 2.

Table 2 Overview of electrospun materials for DSSCs.

\begin{tabular}{|c|c|c|c|c|}
\hline Material & Notes & Dye & Efficiency (AM-1.5G) & Ref. \\
\hline $\begin{array}{l}\mathrm{TiO}_{2} \text { with } \\
\text { adhesion } \\
\text { treatments }\end{array}$ & $\begin{array}{l}\text { Treated with } \\
\text { tetrahydrofuran to } \\
\text { improve adhesion and } \\
\mathrm{TiCl}_{4} \text { to improve } \\
\text { injection efficiency }\end{array}$ & N3 & $\begin{array}{l}4.6 \% \text { gel electrolyte } \\
5.02 \% \text { liquid } \\
\text { electrolyte }\end{array}$ & {$[31,83]$} \\
\hline $\begin{array}{l}\mathrm{TiO}_{2} \\
\text { single-crystalline } \\
\text { nanorods }\end{array}$ & $\begin{array}{l}\text { Hot-pressing technique } \\
\text { fiber treatment and gel } \\
\text { electrolyte }\end{array}$ & N3 & $6.2 \%$ & {$[32]$} \\
\hline $\begin{array}{l}\mathrm{TiO}_{2} \\
\text { single-crystalline } \\
\text { nanorods }\end{array}$ & $\begin{array}{l}\text { Similar to above, } \\
\text { but with liquid electrolyte }\end{array}$ & N3 & $5.77 \%$ & {$[33]$} \\
\hline $\mathrm{ZnO}$ hot-pressed & $\begin{array}{l}\text { Hot-pressed creating a } \\
\text { twisted coral-like } \\
\text { structure }\end{array}$ & N719 & $1.34 \%$ & {$[34]$} \\
\hline $\begin{array}{l}\mathrm{TiO}_{2} \text { ground } \\
\text { fibers and } \\
\text { nanoparticles }\end{array}$ & $\begin{array}{l}\text { Fibers mechanically } \\
\text { ground and sprayed } \\
\text { on substrate }\end{array}$ & N3 & $5.8 \%$ & {$[35]$} \\
\hline $\mathrm{TiO}_{2}$ nanotubes & $\begin{array}{l}\text { PAN template first spun } \\
\text { then impregnated } \\
\text { with } \mathrm{TiCl}_{4}\end{array}$ & NA & Not tested & {$[36]$} \\
\hline $\begin{array}{l}\mathrm{TiO}_{2} \text { adhesion } \\
\text { treatments }\end{array}$ & $\begin{array}{l}\text { Thin treatment layer of } \\
\mathrm{TiCl}_{4} \text {, then treated with } \\
\text { DMF, increasing } \\
\text { membrane thickness } \\
\text { increased efficiency }\end{array}$ & N3 & $4.14 \%$ & [84] \\
\hline $\begin{array}{l}\mathrm{TiO}_{2} \text { particles and } \\
\text { electrospun fibers }\end{array}$ & $\begin{array}{l}\text { Thick layer of particles } \\
\text { covered with } \sim 1 \mu \mathrm{m} \\
\text { electrospun layer }\end{array}$ & N719 & $10.3 \%$ & {$[82]$} \\
\hline $\mathrm{TiO}_{2}$ nanoparticles & $\begin{array}{l}\text { Electrospun fibers burnt } \\
\text { out of } \mathrm{TiO}_{2} \text { layer, leaving } \\
\text { behind a microtube network }\end{array}$ & N3 & $5.55 \%$ & {$[85]$} \\
\hline P(VDF-HFP) & $\begin{array}{l}\text { Electrolyte membrane } \\
\text { improved long-term } \\
\text { stability with liquid electrolyte }\end{array}$ & N719 & $7.3 \%$ & {$[37]$} \\
\hline
\end{tabular}

DSSCs, shown in Fig. 4, are typically composed of a ruthenium-based dye, a charge transport layer, and an electrolyte solution. These layers are enclosed in two transparent conducting oxide layers. The charge transport layer is typically composed of $\mathrm{TiO}_{2}$ nanoparticles, due to their high surface area; 
however, $\mathrm{ZnO}, \mathrm{SnO}_{2}$, and $\mathrm{Al}_{2} \mathrm{O}_{3}$ are also reported [79]. The highest solar cell efficiency has been achieved by Si-based solar cells, which have attained efficiencies as high as $24 \%$ [80]. The most efficient DSSC has a reported efficiency of $11.1 \%$, and electrospun DSSCs have reached an efficiency of $10.3 \%[81,82]$. The following section describes electrospinning developments in DSSCs.

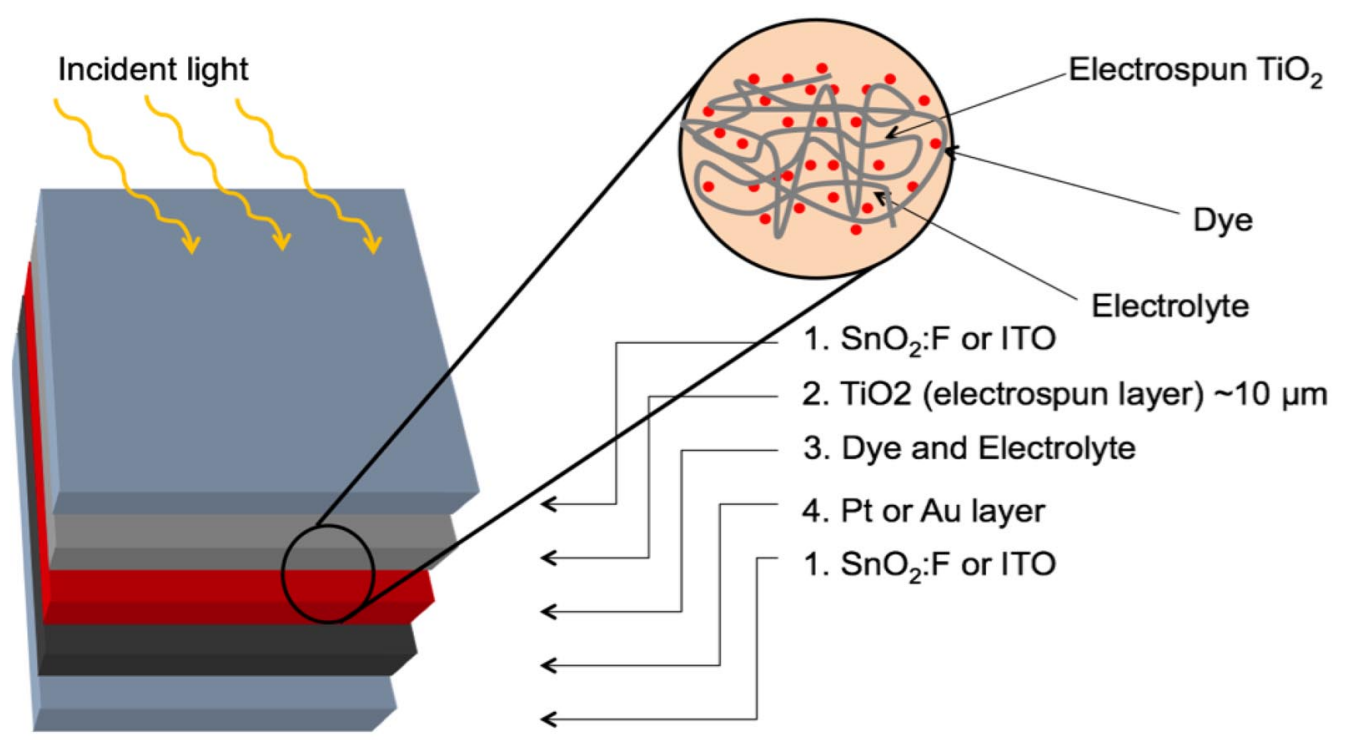

Fig. 4 Schematic of a DSSC. Note that the inner layers do not exist as separate entities, but mix together as shown in the magnified view.

Conversion efficiency $(\eta)$ is the most common description of solar cell performance, which is described by the following equation:

$$
\eta=\frac{P_{\mathrm{max}}}{P_{\text {in }}}=\frac{V_{\mathrm{OC}} J_{\mathrm{SC}} \mathrm{FF}}{P_{\text {in }}}
$$

where FF, $J_{\mathrm{SC}}, V_{\mathrm{OC}}$, and $P_{\text {in }}$ are fill factor, short-circuit current density, open-circuit voltage, and incident power, respectively. Incident power is typically fixed at $100 \mathrm{~mW} / \mathrm{cm}^{2}$ (AM-1.5G) during testing. The limiting parameters of DSSCs are typically reported as follows: slow percolation through the nanoparticle layer, limited light sensitivity of the dye, and poor long-term stability. The following sections discuss how electrospun nanofibers have been investigated to help improve solar cells. These sections are broken down into the impact electrospinning has on electron transport, light scattering, electrolyte stability, and adhesion of the $\mathrm{TiO}_{2}$ layer.

\section{Electron transport}

Several studies have investigated the use of nanofibers to create novel porous structures. These structures have the potential to increase the surface area, create a continuous charge transport route, or increase polymer electrolyte penetration. However, the conversion efficiencies reported are lower than standard solar cells composed entirely of nanoparticles due to a decrease in surface area. Additionally, electrospun fibers tend to have poor adhesion to the substrate, which can be overcome via methods described in the following sections $[31,83,84,86]$.

In an effort to maintain a high surface area as well as increase charge transport, Fujihara et al. incorporated a combination of electrospun nanorods and nanoparticles. The electrospun nanofibers 
(a)
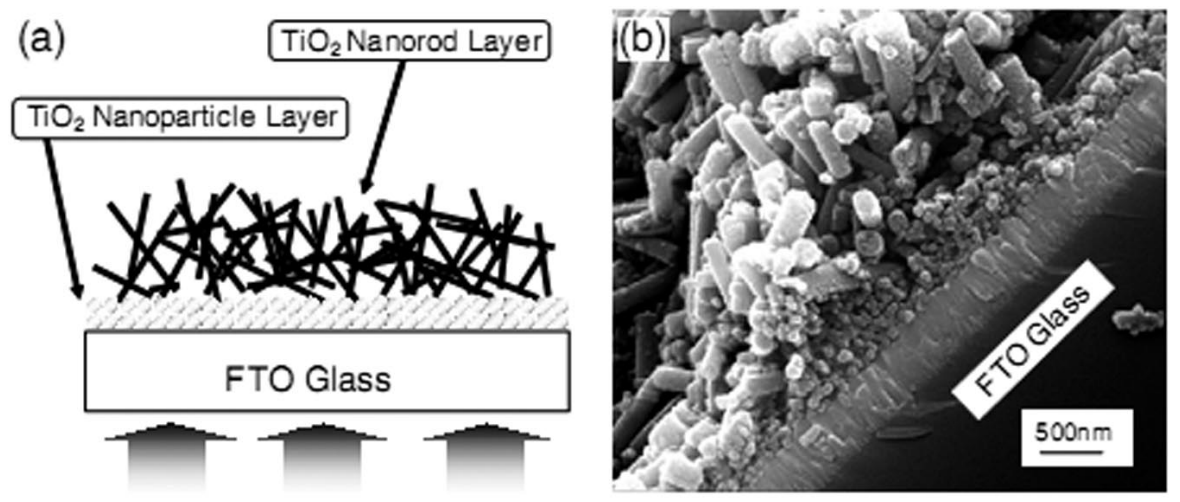

Light Source

Fig. 5 Ground electrospun nanoparticles on a glass plate (a) schematic (b) SEM image. Reprinted with permission from [35].

were mechanically ground, creating nanorods prior to incorporation into the solar cells. These devices show that a combination of rods and nanoparticles improve efficiency over entirely nanorod devices. However, a comparison was not made to a device assembled from nanoparticles alone [35].

Although electrospun materials are typically polycrystalline, altering the processing conditions can result in single-crystal structures. Single-crystal nanofibrils were prepared starting from aligned electrospun fibrils with an islands-in-a-sea morphology. Phase separation of the titania and poly(vinyl acetate) allowed for the formation of single crystal nanofibrils [32,33]. The theory behind the nanofibril formation is described by Jo et al. [87]. The use of single-crystal nanofibers results in an improved efficiency over nanofibers that were ground through mechanical means [32]. This work was further investigated by Kokubo et al. by examining the effects of the applied pressure and membrane thickness on the morphology and photoelectrochemical characteristics [33]. Their results show increasing pressure and layer thickness improve overall efficiency. SEM images of their unusual fiber morphology are shown in Fig. 6.

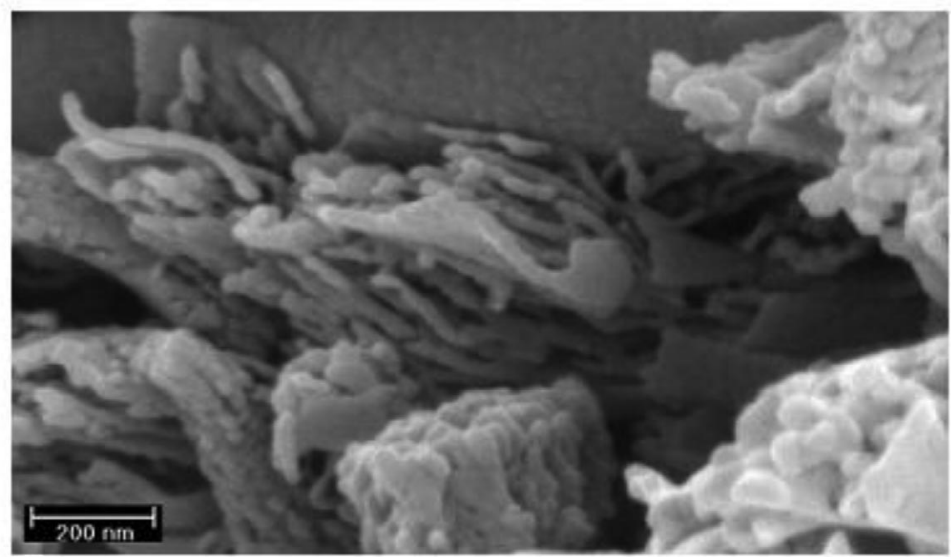

Fig. 6 Cross-sectionional SEM images of fibers calcined after a pressure pretreatment. Reprinted with permission from [33]. 
Chuangchote et al. achieved an overall efficiency of $10.3 \%$, the highest reported efficiency for electrospun DSSCs [82]. In their work, aligned $\mathrm{TiO}_{2}$-rich nanofibril regions within the fiber were created. The fibers were obtained by allowing phase separation of the $\mathrm{TiO}_{2}$ and polymer regions, which resulted in highly aligned fibrils that do no require hot-pressing. The nanofibrils are reported to increase the optical path length through light scattering, which increases the absorption of visible light within the film. Their results coincide with similar work where larger nanoparticles were used in combination with smaller ones to improve light scattering [81].

\section{Light scattering}

Numerous studies have attempted to develop new dyes to increase light absorption in DSSCs, while other work alters the $\mathrm{TiO}_{2}$ layer to enhance efficiency. The dyes do not efficiently absorb the full solar spectrum. Haze refers to the optical path length in solar cells. The concept of "haze" has resulted in DSSCs with a certified efficiency of $11.1 \%$, which is the highest efficiency reported to date using $\mathrm{TiO}_{2}$ nanoparticles held by Sharp Corp. Increasing this parameter, by introducing light-scattering elements through introduction of submicron particles, increases the incident photon to current efficiency, particularly for the red portion of the spectrum [81].

Zhao et al. utilized the concept of haze by creating hollow microtubes within the $\mathrm{TiO}_{2}$ layer. These tubes act as light-scattering centers, which increased the optical path length. Zhao et al. also propose, based on electrochemical impedance data, that the number of trap states is reduced within the sample due to the lower number of nanoparticles. The cells were assembled by sandwiching nanofibers between two $\mathrm{TiO}_{2}$ nanoparticle layers. The nanofibers were then decomposed, creating microtube networks within the film. Figure 7 shows a schematic of the processing steps to create the hollow network [85].

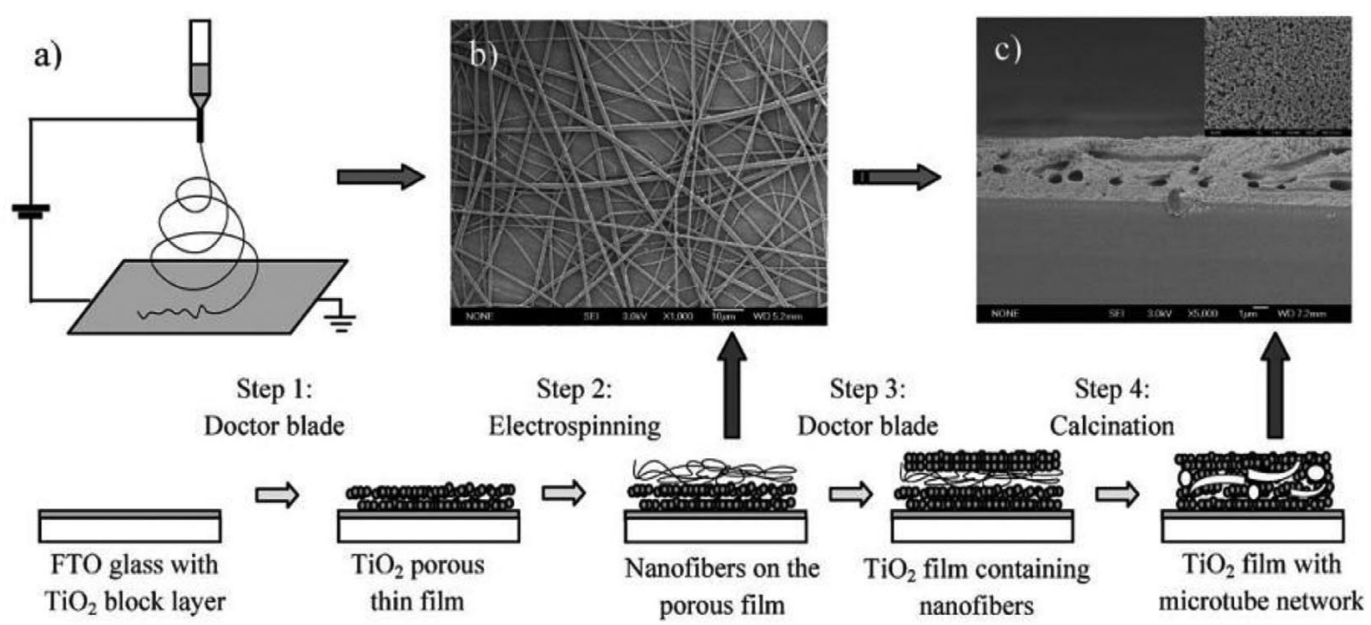

Fig. 7 Microtubes in $\mathrm{TiO}_{2}$ layer from decomposed nanofibers [85]. Reproduced by permission of The Royal Society of Chemistry.

\section{Electrolytes}

The volatility of liquid electrolytes in DSSCs, which typically consists of an $\mathrm{I}^{-} / \mathrm{I}_{3}{ }^{-}$redox couple, is one of the major concerns with this type of cell. Solid-state DSSCs are under development to improve cell stability [88]. One potential advantage of electrospun $\mathrm{TiO}_{2}$ electrodes is an increase in the penetration by polymer gel electrolytes. Polymer gels do not easily penetrate into nanoparticle $\mathrm{TiO}_{2}$ layers; however, the larger pores in electrospun fibers allow the electrolyte to effuse more effectively into the cell. Using this method, Song et al. were able to achieve $90 \%$ of the efficiency of a liquid DSSC [32]. Quasi- 
solid-state solar cells use a polymer cage to trap the electrolyte solution, which increases the electrolyte stability. Priya et al. electrospun poly(vinylidene fluoride-co-hexafluoropropylene) [P(VDF-HFP)] fiber membranes. A cell efficiency of $7.3 \%$, under $100 \mathrm{~mW} / \mathrm{cm}^{2}$ (AM-1.5G), was obtained using this method. Their results show that over time, the quasi-solid-state cells are better able to retain a high light-to-electricity conversion ratio than liquid DSSCs [37]. This work was continued by Kim et al., who tested the impact of the electrospun polymer cage dimensions and morphology and found that little correlation existed between fiber diameter and morphology to the performance of the cell [89].

\section{Adhesion of fibers to the substrate}

Proper adhesion of nanofibers to the substrate is often cited as a concern with cells composed entirely of electrospun fibers [35]. During calcination, ceramic fibers shrink, causing delamination from the substrate. Adhesion is usually improved by either surface treatment or altering the fiber morphology through hot-pressing. Treatment in tetrahydrofuran or dimethylformamide (DMF) vapor is used to partially dissolve the fibers on the surface prior to sintering. This treatment creates interconnected fibers as well as improves adhesion [31,84]. Later attempts realized higher efficiencies through a combination of nanoparticles and electrospun fibers, which also overcomes the adhesion problems of fibers $[35,82,84]$.

In an attempt to improve charge transport as well as adhesion between the fibers and the cell surface, a twisted fiber structure was developed by Kim et al. by hot-pressing $\mathrm{ZnO}$ fibers, shown in Fig. 8 [34]. Onozuka used DMF surface treatments to increase the adhesion between layers [84]. In another study, Zhu et al. improved adhesion between the layers by heating the fibers on a hot plate as it was electrospun [86]. These studies demonstrate that there are numerous ways to overcome the adhesion difficulties that are associated with electrospun fibers.

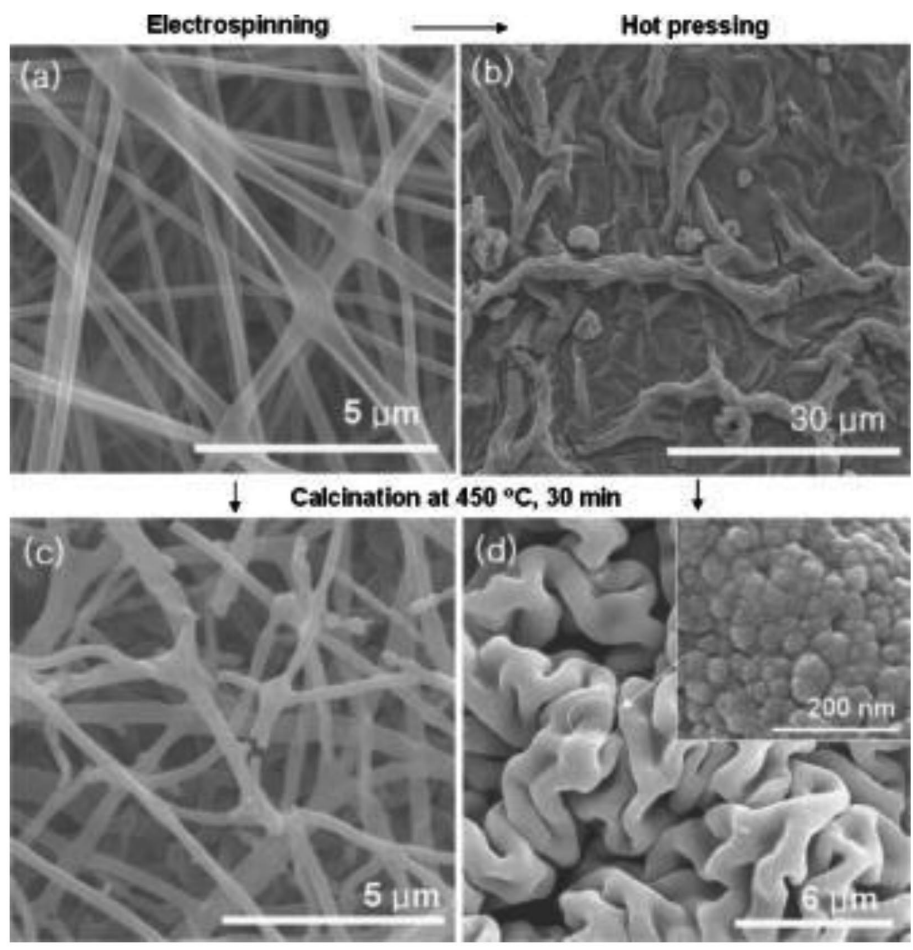

Fig. 8 Effect of hot-pressing on electrospun $\mathrm{ZnO}$ fibers. Reprinted with permission from [34]. Copyright @ 2007 , American Institute of Physics. 
Electrospun fibers have been prepared in order to address many aspects of DSSCs. To this end, many novel morphologies have been explored, which have potential applications in other areas of research as well. One of the greatest obstacles associated with electrospun fibers is the decrease in surface area. Further improvements could be realized by optimizing fiber diameters and morphologies to improve the surface area and dye loading. Another critical aspect of solar cell technology is a means to store the power generated. Efficient battery technology is required to make optimal use of solar cells, as well as in any portable electronic technology. The following section discusses how electrospinning has been applied to the development of battery technologies.

\section{Batteries}

Batteries are closed systems in which there is an inter-conversion of chemical and electrical energy through redox reactions. Similar to fuel cells, batteries consist of an anode, a cathode, and an electrolyte. Frequently, there is also a separator membrane between the anode and cathode that prevents short-circuiting. Developments in battery technology focus on enhancing power densities and increasing the number of cycles to failure. Battery technology is critical for any portable device to operate without immediate grid access.

Lithium-ion battery technology is a recent breakthrough in electrochemistry that has gone on to commercial success. Lithium-ion batteries have the highest energy storage capacity of the rechargeable battery systems and have allowed for the powering of portable electronic devices [90]. While lithiumion batteries have enabled the proliferation of small, portable, consumer electronic devices, the size and power of available batteries is frequently the limiting factor in the launch of new products. Commercial lithium-ion batteries can operate at around $4 \mathrm{~V}$, with practical energy and power densities of $150 \mathrm{Wh} / \mathrm{kg}$ and $1000 \mathrm{~W} / \mathrm{kg}$, respectively [91]. Larger, more demanding applications, such as powering electric vehicles, also require significant breakthroughs in battery technology.

While lithium metal has the highest theoretical capacity of any battery anode, its tendency to form dendritic growths during recharging necessitates the use of host materials. Therefore, batteries are designed such that lithium-ions intercalate into host materials at the anode and cathode. Electrospun host materials offer advantages such as reduced material dimensions for the shorter diffusion path of the lithium-ions, minimized disintegration during cycling due to large volume changes, and elimination of the need for binders and electrically conductive additives. Electrospinning is also a relatively lowcost process that can be utilized to create nanostructured core-shell, aligned, or cross-bar geometries. Electrospun fiber mats can also serve as electrode separator membranes with the similar benefits of reduced dimensions and manufacturing costs. Recent research in the areas of electrospun anodes, cathodes, and separator membranes is summarized.

\section{Anodes}

Electrospun anode materials can be grouped into three categories: carbon fiber, transition-metal oxide, and polymer fibers loaded with metal nanoparticles. Overall, the fibers produced range between 100 to $1000 \mathrm{~nm}$ with 8-50-nm-sized grains [38,41,42,46,92-97]. Carbon fiber anodes were prepared from heat-treated polyacrylonitrile (PAN) and are reported to have fiber diameters between $200-300 \mathrm{~nm}$ $[1-3,38,92,93]$. Of the pure carbon fiber materials, Kim et al. reported the highest reversible capacity of $450 \mathrm{~mA} \mathrm{~h} / \mathrm{g}$ for samples that were heat-treated at $1000{ }^{\circ} \mathrm{C}$ [92]. Carbon fiber anodes have also been loaded with transition-metal oxide nanoparticles such as $\mathrm{MnO}_{x}$ and $\mathrm{Fe}_{3} \mathrm{O}_{4}$ [46,94]. Fan et al. report that synthetic carbon has a potential that is close to that of lithium metal and that this could lead to the deposition of lithium metal on the anode and subsequently result in dendrite formation [98]. In order to avoid this deposition, they produced fibers composed of manganese oxide, which has a potential further from lithium, and polymethylmethacrylate (PMMA), which were calcined to burn out the polymer [98]. Of the two manganese oxide investigations, the carbon fiber $/ \mathrm{MnO}_{x}$ resulted in a higher reversible capacity of $592 \mathrm{mAh} / \mathrm{g}$ after 50 cycles, while the capacity of pure $\mathrm{MnO}$ was $450 \mathrm{mAh} / \mathrm{g}$ after the same 
number of cycles $[94,98]$. The carbon- $\mathrm{Fe}_{3} \mathrm{O}_{4}$ composite fiber, however, maintained the highest reversible capacity of the electrospun anode material reported; this value was $1007 \mathrm{mAh} / \mathrm{g}$ after 80 cycles [42].

Interestingly, several studies have reduced metal compounds within electrospun fibers via posttreatment conditions. Wang et al. added cobalt acetate to their PAN/DMF electrospinning solution [95]. During the initial heat treatment, the cobalt acetate was oxidized along with the PAN to form cobalt oxide; in the second heat treatment, the fibers are reduced to carbon and cobalt metal nanoparticles at $600{ }^{\circ} \mathrm{C}$ under argon [95]. Gu et al. and Ding et al. electrospun cobalt precursor solutions and obtained cobalt oxide fibers after heat treatment in air $[42,96]$. Yagi et al. embedded 30-nm tin nanoparticles in poly(L-lactic acid) (PLLA) fibers with submicron diameters. It was noted that the PLLA protected the tin nanoparticles from oxidation in air [97].

\section{Cathodes}

Several groups have reported electrospinning of transition-metal oxide and polymer fiber cathodes for lithium-ion batteries. The oxide fibers have layered, rock-salt, $\alpha-\mathrm{NaFeO}_{2}$, anatase, and spinel phases. Fibers as narrow as $50 \mathrm{~nm}$ have been achieved [44,45,50,51,99-108]. Fiber geometries such as nanobelts, tubes, core-shell, core-shell tubes, and cross-bar hierarchical structures have been accomplished through alterations to the electrospinning apparatus [44,45,50,51,100-102]. Electrospun fibers made of layered vanadium compounds $\mathrm{Li}_{1+\mathrm{a}} \mathrm{V}_{3} \mathrm{O}_{8}$ and $\mathrm{V}_{2} \mathrm{O}_{5}$ had high reversible capacities of 255 $\mathrm{mAh} / \mathrm{g}$ after 40 cycles and $240 \mathrm{mAh} / \mathrm{g}$ after 25 cycles, respectively [100,103]. The highest electrochemical capacity was reported for NiO/single-wall carbon nanotube (SWCNT) composite fiber; after 20 cycles, the electrochemical capacity had only reduced to $337 \mathrm{mAh} / \mathrm{g}$. These fibers performed much better compared to pure $\mathrm{NiO}$ fibers that obtained a reversible capacity of $275 \mathrm{mAh} / \mathrm{g}$. Due to the mechanical strength and conductivity of the SWCNTs, the cathode made of the calcined fibers did not need to be mixed with a binder or conductive agents [99]. Ju et al. report on the novel use of an electrospun polymer cathode. Their polypyrrole/sulfonated poly(styrene-ethylene-butylenes-styrene) was able to maintain $78 \mathrm{mAh} / \mathrm{g}$ after 100 cycles [61].

Lu et al. electrospun fibers into cross-bar structures in order to improve lithium-ion diffusion to the cathode materials; the cross-bar structure was obtained by electrospinning one layer of parallel fibers across a $1-\mathrm{cm}$ gap in the collector electrode, then rotating the electrode for the subsequent perpendicular layer [51,102]. One of their reports compared anatase $\mathrm{TiO}_{2}$ to spinel $\mathrm{Li}_{4} \mathrm{Ti}_{5} \mathrm{O}_{12}$; they found the spinel phase to be a zero strain lithium insertion host that did not degrade during cycling like the anatase phase [43]. In another report, Lu et al. improved the stability of their $\mathrm{LiCoO}_{2}$ cross-bar fibers by coating them with lithium phosphorous oxynitride [102]. Several papers have reported electrospun tubes and core-shell fibers $[44,45,50,101]$. However, $\mathrm{Gu}$ et al. synthesized core-shell tubes that consist of fiber with concentric layers of $\mathrm{MgO}$ and $\mathrm{LiNi}_{0.8} \mathrm{Co}_{0.1} \mathrm{Mn}_{0.1} \mathrm{O}_{2}$ and a hollow core. While other approaches had used machine oil to create the void in the tubes, the voids in the core-shell tubes formed from the concentration of the polyvinyl pyrrolidone core toward the $\mathrm{MgO}$ shell during heat treatment $[44,45,101]$. The reversible capacity for the core-shell tubes proved higher than that for the core-shell solid fibers and the hollow and solid $\mathrm{LiNi}_{0.8} \mathrm{Co}_{0.1} \mathrm{Mn}_{0.1} \mathrm{O}_{2}$ fibers, which were 174, 159, 141, and 126 $\mathrm{mAh} / \mathrm{g}$, respectively [101].

\section{Membranes}

Electrospinning of lithium-ion battery separator membranes has been heavily reported [55,57,58,60,63,109-129]. A recent review on lithium battery separator membranes made from gel polymer electrolytes highlights that the electrospun fiber membranes are promising due to the inherently connected pores and large surface area [130]. The majority of the original works focused on fabricating membranes from poly(vinylidene fluoride) (PVDF) and PVDF composites and copolymers [55,57,58,63,109-126]. Electrospinning of (PAN) and composites containing PAN was also reported [57,60,116,127-129]. Polymer blends of PVDF and polydiphenylamine, PMMA, and polyintides have 
been electrospun $[55,57,60,110] . \mathrm{SiO}_{2}$ nanoparticles of 3-12 $\mathrm{nm}$ diameters have been electrospun in P(VDF-HFP) with up to 9 wt \% nanoparticles [115].

\section{Capacitors}

Capacitors store energy on two conductors that are separated by a dielectric material. For the simple case of two metal plates, the capacitance, eq. 3 , is governed by the dielectric constant $\left(\varepsilon_{\mathrm{r}}\right)$, permittivity of free space $\left(\varepsilon_{0}\right)$, surface area $(A)$, and distance between electrodes $(d)$.

$$
\mathrm{C}=\varepsilon_{\mathrm{r}} \varepsilon_{0} \frac{A}{d}
$$

Electrochemical double-layer capacitors (EDLCs), also called supercapacitors, offer specific and volumetric capacitances that are several orders of magnitude higher than those of traditional capacitors. EDLCs can have higher power densities than batteries, but have lower energy densities [90]. EDLC electrodes incorporating an electrospinning process step have high surface areas due to nanometer-sized pores between fibers. This allows for large areas for charge storage and double-layer thicknesses on the order of nanometers.

The majority of the reports on electrospun capacitor electrode materials focused on PAN, polybenzimidazole, and poly(amic acid) fibers that were subsequently carbonized [64-66,131-134]. Some carbon fibers were also activated in steam, while Im et al. activated carbon fibers with potassium hydroxide (KOH) solution [64-66,131-133]. Im and Park et al. loaded fibers with vanadium and silver nanoparticles, respectively [133,134]. The highest reported specific capacity was $250 \mathrm{~F} / \mathrm{g}$ for the silver nanoparticle-loaded carbonized fibers [134]. Of the pure activated carbon fibers, $202 \mathrm{~F} / \mathrm{g}$ was the highest reported specific capacity, which the author attributed to the large surface area of the fibers [131]. The diameters of the fibers reported ranged from $185 \mathrm{~nm}$ to a couple of micrometers [66,134]. Nguyen et al. reported on the electrospinning of poly(3,4-ethylenedioxythiophene) webs for use as electrochemical capacitors [135].

\section{Hydrogen storage}

Hydrogen is a particularly interesting energy currency because its combustion process is a completely clean reaction: $2 \mathrm{H}_{2}+\mathrm{O}_{2} \rightarrow 2 \mathrm{H}_{2} \mathrm{O}$. In order to develop a hydrogen-based economy, several obstacles in hydrogen storage must be overcome due to the low volumetric density of $\mathrm{H}_{2}$ gas. Compressed and liquid-based hydrogen storage methods are impractical and unsafe for transportation. Advances in hydrogen storage require a large hydrogen density, favorable energetics for hydrogen release, and economic feasibility [3]. Metal hydrides, chemical hydrides, and carbon materials are the focus of many research projects [136]. Several methods exist to create highly porous, lightweight carbon structures, which include the use of electrospun fibers to create carbon networks. Hydrogen is able to adsorb onto the carbon surface, which allows a higher hydrogen storage capacity. Effectively measuring hydrogen storage capacity has proven difficult, and numerous studies have reported erroneously high values. The highest verified capacities are below $0.8 \mathrm{wt} \%$ at $100 \mathrm{~atm}$ and $300 \mathrm{~K}$. This is still well below the U.S. Department of Energy's target of $6.5 \mathrm{wt} \%$. Carbon materials are reported with Brunauer-Emmett-Teller (BET) surface areas of up to $3700 \mathrm{~m}^{2} \mathrm{~g}^{-1}$ [137].

In a typical process, polymers such as PAN are electrospun. The green fibers are cross-linked in air and heat-treated under inert atmosphere. The carbonized fibers are activated in a solution, such as $\mathrm{KOH}$, to increase the surface area. Several of the studies resulted in higher adsorption than the surface areas predict, which Im et al. suggest is due to the presence of ultramicropores. These pores are not well characterized by the nitrogen adsorption isotherms used in the studies. The pore volume in the range of $0.6-0.7 \mathrm{~nm}$ is shown to be a much more important factor in hydrogen sorption than the surface mor- 
phology or specific surface area in activated carbon nanofibers in a study comparing various activation methods of carbon fibers [138].

In order to enhance hydrogen uptake, a process known as catalyzed hydrogen spillover can greatly enhance hydrogen sorption and desorption rates. This phenomenon is caused by dissociate chemisorption of $\mathrm{H}_{2}$ on a metal. After $\mathrm{H}_{2}$ is dissociated into elemental hydrogen, it is transferred to the hydrogen supporting surface [139]. Im et al. investigated this phenomenon using several catalysts. An embedded vanadium catalyst reportedly exhibited this effect on hydrogen storage, achieving a capacity of $2.5 \mathrm{wt} \%$. The vanadium also served to increase the specific surface area with a large increase in the number of pores in the $0.6 \mathrm{~nm}$ range [140]. Further increases were realized by an investigation into a metal-carbon-fluorine system with $\mathrm{KOH}$ activation. Im et al. went on to study the effects of copper oxide, magnesium oxide, iron oxide, magnesium, and iron embedded as catalysts in carbon fibers. The pore structure varied based on the metals used. The pure metals were reported to be more effective catalysts, and, in particular, copper oxide, which dissociated to pure copper, attained the highest adsorption capacity in this study of $2.8 \mathrm{wt} \%$ at 100 bar at room temperature [74].

While these studies test various methods to improve the porosity within the fibers themselves, they do little to investigate the effect of fiber morphology, the one feature that is unique to the use of electrospun fibers. It is possible that carbon fibers might help in the development of well-defined pore structures; however, no comparison is made to other techniques in these studies [141]. Further investigations should attempt to determine the influence of fiber size and pore structure on hydrogen uptake.

Table 3 Summary of performance of electrospun materials for hydrogen storage, measured at 100 bar at room temperature.

\begin{tabular}{|c|c|c|c|c|c|}
\hline $\begin{array}{l}\text { Starting } \\
\text { material }\end{array}$ & Treatment & Resulting system & $\begin{array}{c}\text { Specific } \\
\text { surface area } \\
\left(\mathrm{m}^{2} / \mathrm{g}\right)\end{array}$ & $\begin{array}{l}\text { Storage } \\
\text { capacity } \\
\text { (wt \%) }\end{array}$ & Ref. \\
\hline PAN & Carbonization & Nonporous C & $22-31$ & $0.16-0.5$ & {$[141]$} \\
\hline PAN & $\begin{array}{l}\mathrm{Fe}(\mathrm{III}) \\
\text { acetylacetonate }\end{array}$ & Porous graphite & $60-253$ & $0.14-1.01$ & {$[141]$} \\
\hline PAN & $\mathrm{KOH}$ & Activated porous $\mathrm{C}$ & 2420 & 1.03 & {$[138]$} \\
\hline PAN & $\mathrm{ZnCl}_{2}$ & Activated porous $\mathrm{C}$ & 944 & 1.54 & {$[138]$} \\
\hline PAN & $\mathrm{KOH}$ & Activated porous $\mathrm{C}$ & 2880 & $\sim 2.1$ & [74] \\
\hline PAN with $\mathrm{CuO}$ & $\mathrm{KOH}$ & Pure $\mathrm{Cu}$ in porous $\mathrm{C}$ & 2820 & 2.77 & [74] \\
\hline PAN with $\mathrm{MgO}$ & $\mathrm{KOH}$ & $\mathrm{MgO}$ in porous $\mathrm{C}$ & 2130 & 1.69 & [74] \\
\hline PAN with $\mathrm{FeO}$ & $\mathrm{KOH}$ & $\mathrm{FeO}$ in porous $\mathrm{C}$ & 1480 & 1.33 & [74] \\
\hline PAN with Mg & $\mathrm{KOH}$ & $\mathrm{Mg}$ in porous $\mathrm{C}$ & 1230 & 2.29 & [74] \\
\hline PAN with $\mathrm{Fe}$ & $\mathrm{KOH}$ & $\mathrm{Fe}$ in porous $\mathrm{C}$ & 1040 & 2.05 & [74] \\
\hline PVDF & $\begin{array}{l}\text { Carbonized with } \\
\text { Fe(III) } \\
\text { acetylacetonate }\end{array}$ & $\begin{array}{l}\text { Porous graphite/ } \\
\text { porous C } \\
\text { (measured at } 80 \text { bar) }\end{array}$ & $473 / 1300$ & $0.11-0.18 / 0.39$ & [75] \\
\hline PAN with $\mathrm{V}_{2} \mathrm{O}_{5}$ & $\mathrm{KOH}$ & $\begin{array}{l}\text { V-embedded } \\
\text { porous carbon }\end{array}$ & 2780 & 2.5 & {$[140]$} \\
\hline PAN with $\mathrm{V}_{2} \mathrm{O}_{5}$ & $\begin{array}{l}\mathrm{KOH} \text { and } \\
\text { fluorination }\end{array}$ & $\begin{array}{l}\text { V-embedded } \\
\text { porous fluorinated } \mathrm{C}\end{array}$ & 2800 & 3.2 & {$[77]$} \\
\hline
\end{tabular}

\section{Fuel cells}

Fuel cells are one of the most promising energy-related technologies due to their high efficiency, quiet operation, and limited output of pollution [142]. Through electrochemical reactions, fuel cells are able to turn chemical energy, in the form of fuel, into electrical energy. There are many potential fuel cell designs including: direct methanol fuel cells, solid oxide fuel cells, and biofuel cells [142-145]. The 
high cost of the catalyst material in the electrode, typically platinum, limits the marketability of fuel cells [146]. Fibers that are electrospun from conducting polymers provide a large surface area for the catalyst material as well as providing electrical conductivity to the substrate.

Several studies have investigated carbon nanofibers made by electrospinning methods. Li et al. synthesized conducting carbon fiber mats through carbonization of PAN fibers. Chemical vapor deposition methods were then used to attach the platinum nanoclusters [69]. Their catalyst improved stability and activity over a commercial carbon-supported platinum electrode despite its less desirable morphology and distribution of the catalyst. Kim et al. also reported high conductivities with platinum and platinum-rhodium catalysts in polymer electrolyte membrane fuel cells. The polymer portion of the fiber was removed through calcination, leaving behind platinum and platinum-rhodium bimetallic wires that are $1 / 5^{\text {th }}$ the diameter of the as-spun fibers [68].

Proton exchange fuel cells require special membranes that have high proton transport and solvent uptake as well as suitable mechanical properties, which are highly sensitive to the membrane microstructure. A proton conductivity of $0.37 \mathrm{~S} / \mathrm{cm}$ was achieved by $\mathrm{Li}$ et al., using sulfonated poly(ether ether ketone ketone) electrospun fibers. The reported conductivity is higher than membranes produced from typical casting methods [71]. Another study investigated Nafion impregnated electrospun fibers of PVDF. These fibers exhibited lower proton conductivity than Nafion 115; however, in methanol fuel cells, the fibers limited methanol cross-over, which yielded a higher overall performance than Nafion 115 [72].

Several environmentally sustainable fuel cells have been proposed, including glucose- and enzyme-powered cells. Glucose-based fuel cells have the potential to convert biomass waste into a fuel source. A low-cost glucose cell was prepared by Schechner et al. Polycaprolactone was electrospun into mats as part of a catalytic anode, and plated with silver. The cells exhibited low power density, indicating further work is needed to develop these cells. Enzyme-powered cells tend to have short life-times and low power densities [147]. Another study has prepared enzyme-carrying polystyrene nanofibers with the potential to improve enzyme lifespan and activity [73].

\section{CONCLUSIONS}

Electrospinning is a versatile process that is used to create long-length-scale fibers with great potential in a wide range of energy applications. Through electrospinning, a wide range of ceramic and polymer materials can be made into fibrous structures with high surface-area-to-volume ratios. Innovative techniques continue to be developed to alter fiber morphologies and orientation to create complex architectures. These materials have applications that include solar cells, batteries, capacitors, fuel cells, and hydrogen storage technologies.

Electrospinning for energy-related applications is in its nascent stages of development. However, the current state of research has demonstrated a promising role of electrospinning in many applications. One of the current drawbacks for introduction of electrospun materials into the mass market is the small quantity of fibers that can be produced per spinneret, which is on the order of milligrams per hour. However, a number of companies have been established that work with thousands of spinnerets or with free surfaces that forgo spinnerets altogether. As of 2009, the production limits are around $200 \mathrm{~kg}$ of nanofibers per day for the largest factories. Further advancements in the production of large quantities of fibers with the advanced properties reviewed in this work could lead to the widespread adoption of this process.

Continued development of these technologies could improve the viability of clean energy systems and increase the capacity and discharge rates of storage devices. These advancements are needed to help cope with rapid population growth and continued depletion of non-renewable resources. It is hoped that this will lead to a decrease in reliance on foreign oil and more efficient use of natural resources. Furthermore, the portability of these devices allows power sources to be brought to areas that lack grid 
access. In these locations, a combination of energy storage and harvesting devices can produce lighting, run purification systems, or even be used to prepare food.

\section{ACKNOWLEDGMENTS}

This work was in part supported by WCU (World Class University) program through the Korea Science and Engineering Foundation (R31-2008-000-10092). The authors would also like to acknowledge financial support from the Alumni Fellowship Program of the University of Florida.

\section{REFERENCES}

1. Energy Information Administration. Available online at <http://www.eia.doe.gov/emeu/aer> Last accessed August 2009.

2. M. Ayad, S. Pierfederici, S. Rael, B. Davat. Energy Conversion Management 48, 2196 (2007).

3. S. Orimo, Y. Nakamori, J. Eliseo, A. Zuttel, C. Jensen. Chem. Rev. 107, 4111 (2007).

4. Z. Huang, Y. Zhang, M. Kotaki, S. Ramakrishna. Compos. Sci. Technol. 63, 2223 (2003).

5. R. Ramaseshan, S. Sundarrajan, R. Jose, S. Ramakrishna. J. Appl. Phys. 102, 111101 (2007).

6. V. Thavasi, G. Singh, S. Ramakrishna. Energy Environ. Sci. 1, 205 (2008).

7. S. Ramakrishna, K. Fujihara, W. Teo, T. Yong, Z. Ma, R. Ramaseshan. Mater. Today 9, 40 (2006).

8. S. Tan, X. Huang, B. Wu. Polym. Int. 56, 1330 (2007).

9. T. Ciach, E. Diaz, E. Van Den Ijssel, J. Marijnissen. Optimization Aerosol Drug Delivery 189 (2003).

10. A. Formhals. U.S. Patent 1,975,504, issued 2 Oct 1934.

11. S. Fridrikh, J. Yu, M. Brenner, G. Rutledge. Phys. Rev. Lett. 90, 144502 (2003).

12. T. Subbiah, G. Bhat, R. Tock, S. Parameswaran, S. Ramkumar. J. Appl. Polym. Sci. 96, 557 (2005).

13. W. Sigmund, J. Yuh, H. Park, V. Maneeratana, G. Pyrgiotakis, A. Daga, J. Taylor, J. Nino. J. Am. Ceram. Soc. 89, 395 (2006).

14. W. Teo, S. Ramakrishna. Nanotechnology 17, R89 (2006).

15. W. Gilbert, P. Mottelay. De Magnete, Dover Publications (1958).

16. M. Hohman, M. Shin, G. Rutledge, M. Brenner. Phys. Fluids 13, 2221 (2001).

17. D. Reneker, A. Yarin, H. Fong, S. Koombhongse. J. Appl. Phys. 87, 4531 (2000).

18. H. Dong, V. Nyame, A. MacDiarmid, W. Jones Jr. J. Polym. Sci., Part B: Polym. Phys. 42, 3934 (2004).

19. J. Deitzel, J. Kleinmeyer, D. Harris, N. Beck Tan. Polymer 42, 261 (2001).

20. M. Hey, D. Jackson, H. Yan. Polymer 46, 2567 (2005).

21. J. Grace, J. Marijnissen. J. Aerosol Sci. 25, 1005 (1994).

22. B. Sundaray, V. Subramanian, T. Natarajan, R. Xiang, C. Chang, W. Fann. Appl. Phys. Lett. 84, 1222 (2004).

23. H. Pan, L. Li, L. Hu, X. Cui. Polymer 47, 4901 (2006).

24. D. Li, Y. Wang, Y. Xia. Adv. Mater. 16, 361 (2004).

25. D. Li, Y. Wang, Y. Xia. Nano Lett. 3, 1167 (2003).

26. A. Theron, E. Zussman, A. Yarin. Nanotechnology 12, 384 (2001).

27. J. Deitzel, J. Kleinmeyer, J. Hirvonen, N. Beck Tan. Polymer 42, 8163 (2001).

28. D. Yang, B. Lu, Y. Zhao, X. Jiang. Adv. Mater. 19, 3702 (2007).

29. Z. Sun, E. Zussman, A. Yarin, J. Wendorff, A. Greiner. Adv. Mater. 15, 1929 (2003).

30. D. Li, Y. Xia. Nano Lett. 4, 933 (2004).

31. M. Song, D. Kim, K. Ihn, S. Jo, D. Kim. Nanotechnology 15, 1861 (2004).

32. M. Song, Y. Ahn, S. Jo, D. Kim, J. Ahn. Appl. Phys. Lett. 87, 113113 (2005).

33. H. Kokubo, B. Ding, T. Naka, H. Tsuchihira, S. Shiratori. Nanotechnology 18, 165604 (2007).

(C) 2010, IUPAC

Pure Appl. Chem., Vol. 82, No. 11, pp. 2137-2156, 2010 
34. I. Kim, J. Hong, B. Lee, D. Kim, E. Jeon, D. Choi, D. Yang. Appl. Phys. Lett. 91, 163109 (2007).

35. K. Fujihara, A. Kumar, R. Jose, S. Ramakrishna, S. Uchida. Nanotechnology 18, 365709 (2007).

36. Y. Qiu, J. Yu. Solid State Commun. 148, 556 (2008).

37. A. R. S. Priya, A. Subramania, Y. S. Jung, K. J. Kim. Langmuir 24, 9816 (2008).

38. L. Ji, X. Zhang. Nanotechnology 20, 155705 (2009).

39. S. Yagi, T. Nakagawa, E. Matsubara, S. Matsubara, S. Ogawa, H. Tani. Electrochem. Solid-State Lett. 11, E25 (2008).

40. L. Wang, Y. Yu, P. Chen, C. Chen. Scri. Mater. 58, 405 (2008).

41. Q. Fan, M. Whittingham. Electrochem. Solid-State Lett. 10, A48 (2007).

42. Y. Ding, P. Zhang, Z. Long, Y. Jiang, J. Huang, W. Yan, G. Liu. Mater. Lett. 62, 3410 (2008).

43. K. Lee, K. Manesh, K. Kim, A. Gopalan. J. Nanosci. Nanotechnol. 9, 417 (2009).

44. S. H. Zhan, Y. Li, H. B. Yu. J. Dispersion Sci. Technol. 29, 702 (2008).

45. S. H. Zhan, Y. Li, H. B. Yu. J. Dispersion Sci. Technol. 29, 823 (2008).

46. L. Wang, Y. Yu, P. Chen, D. Zhang, C. Chen. J. Power Sources 183, 717 (2008).

47. N. Barakat, M. Khil, F. Sheikh, H. Kim. J. Phys. Chem. C 112, 12225 (2008).

48. J. Kuo, S. Lee, K. Hsu, S. Liu, B. Chou, Y. Fu. Mater. Lett. 62, 4594 (2008).

49. Y. Gu, F. Jian. J. Phys. Chem. C 112, 20176 (2008).

50. Y. X. Gu, D. R. Chen, X. L. Jiao, F. F. Liu. J. Mater. Chem. 17, 1769 (2007).

51. H. Lu, W. Zeng, Y. Li, Z. Fu. J. Power Sources 164, 874 (2007).

52. Y. Gu, D. Chen, X. Jiao, F. Liu. J. Mater. Chem. 16, 4361 (2006).

53. N. Yu, C. Shao, Y. Liu, H. Guan, X. Yang. J. Colloid Interface Sci. 285, 163 (2005).

54. L. Zhao, H. Zhang, X. Li, J. Zhao, C. Zhao, X. Yuan. J. Appl. Polym. Sci. 111, 3104 (2009).

55. Y. Ding, P. Zhang, Z. Long, Y. Jiang, F. Xu, W. Di. J. Membr. Sci. 329, 56 (2009).

56. A. Subramania, N. K. Sundaram, A. S. Priya, G. V. Kumar. J. Membr. Sci. 294, 8 (2007).

57. D. Bansal, B. Meyer, M. Salomon. J. Power Sources 178, 848 (2008).

58. M. A. Kader, S. K. Kwak, S. L. Kang, J. H. Ahn, C. Nah. Polym. Int. 57, 1199 (2008).

59. P. Raghavan, X. Zhao, J. Kim, J. Manuel, G. Chauhan, J. Ahn, C. Nah. Electrochim. Acta 54, 228 (2008).

60. T. Cho, T. Sakai, S. Tanase, K. Kimura, Y. Kondo, T. Tarao, M. Tanaka. Electrochem. Solid-State Lett. 10, A159 (2007).

61. Y. Ju, J. Park, H. Jung, W. Lee. Electrochim. Acta 52, 4841 (2007).

62. W. Xiao, Z. Li, Z. Huang, S. Tan. Acta Chim. Sinica 65, 2097 (2007).

63. G. Cheruvally, J. K. Kim, J. W. Choi, J. H. Ahn, Y. J. Shin, J. Manuel, P. Raghavan, K. W. Kim, H. J. Ahn, D. S. Choi, C. E. Song. J. Power Sources 172, 863 (2007).

64. C. Kim, S. H. Park, W. J. Lee, K. S. Yang. Electrochim. Acta 50, 877 (2004).

65. C. Kim, K. S. Yang. Appl. Phys. Lett. 83, 1216 (2003).

66. C. Kim, Y. O. Choi, W. J. Lee, K. S. Yang. Electrochim. Acta 50, 883 (2004).

67. J. Li, E.-h. Liu, W. Li, X.-y. Meng, S.-t. Tan. J. Alloys Compd. 478, 371 (2009).

68. H. J. Kim, Y. S. Kim, M. H. Seo, S. M. Choi, W. B. Kim. Electrochem. Commun. 11, 446 (2009).

69. M. Y. Li, G. Y. Han, B. S. Yang. Electrochem. Commun. 10, 880 (2008).

70. P. Schechner, E. Kroll, E. Bubis, S. Chervinsky, E. Zussman. J. Electrochem. Soc. 154, B942 (2007).

71. X. F. Li, X. F. Hao, D. Xu, G. Zhang, S. L. Zhong, H. Na, D. Y. Wang. J. Membr. Sci. 281, 1 (2006).

72. S. Choi, Y. Fu, Y. Ahn, S. Jo, A. Manthiram. J. Power Sources 180, 167 (2008).

73. H. Jia, G. Zhu, B. Vugrinovich, W. Kataphinan, D. Reneker, P. Wang. Biotechnol. Prog. 18, 1027 (2002).

74. J. S. Im, S. J. Park, T. Kim, Y. S. Lee. Int. J. Hydrogen Energy 34, 3382 (2009).

75. S. E. Hong, D. K. Kim, S. M. Jo, D. Y. Kim, B. D. Chin, D. W. Lee. Catal. Today 120, 413 (2007).

76. E. Zussman, A. L. Yarin, A. V. Bazilevsky, R. Avrahami, M. Feldman. Adv. Mater. 18, 348 (2006). 
77. J. S. Im, S. J. Park, Y. S. Lee. Int. J. Hydrogen Energy 34, 1423 (2009).

78. A. Heeger, C. Brabec. Adv. Mater 18, 789 (2006).

79. M. Law, L. Greene, A. Radenovic, T. Kuykendall, J. Liphardt, P. Yang. J. Phys. Chem. B 110, 22652 (2006).

80. M. Green, K. Emery, Y. Hisikawa, W. Warta. Prog. Photovoltaics 15, 425 (2007).

81. Y. Chiba, A. Islam, Y. Watanabe, R. Komiya, N. Koide, L. Han. Jpn. J. Appl. Phys., Part 245 , L638 (2006).

82. S. Chuangchote, T. Sagawa, S. Yoshikawa. Appl. Phys. Lett. 93, 033310 (2008).

83. M. Song, D. Kim, S. Jo, D. Kim. Synth. Met. 155, 635 (2005).

84. K. Onozuka, B. Ding, Y. Tsuge, T. Naka, M. Yamazaki, S. Sugi, S. Ohno, M. Yoshikawa, S. Shiratori. Nanotechnology 17, 1026 (2006).

85. Y. Zhao, J. Zhai, T. Wei, L. Jiang, D. Zhu. J. Mater. Chem. 17, 5084 (2007).

86. R. Zhu, C. Jiang, X. Liu, B. Liu, A. Kumar, S. Ramakrishna. Appl. Phys. Lett. 93, 013102 (2008).

87. S. M. Jo, M. Y. Song, Y. R. Ahn, C. R. Park, D. Y. Kim. J. Macromol. Sci., Pure Appl. Chem. A42, 1529 (2005).

88. B. Li, L. Wang, B. Kang, P. Wang, Y. Qiu. Sol. Energy Mater. Sol. Cells 90, 549 (2006).

89. J. Kim, S. Park, H. Choi, W. Lee, J. Lee, M. Kim. Sol. Energy Mater. Sol. Cells 93, 803 (2008).

90. M. Winter, R. Brodd. Chem. Rev. 104, 4245 (2004).

91. "Progress report for energy storage research and development," the Report for the DOE BES Workshop (2006).

92. C. Kim, K. S. Yang, M. Kojima, K. Yoshida, Y. J. Kim, Y. A. Kim, M. Endo. Adv. Funct. Mater. 16, 2393 (2006).

93. L. W. Ji, X. W. Zhang. Electrochem. Commun. 11, 684 (2009).

94. L. W. Ji, X. W. Zhang. Electrochem. Commun. 11, 795 (2009).

95. L. Wang, Y. Yu, P. C. Chen, C. H. Chen. Scr. Mater. 58, 405 (2008).

96. Y. X. Gu, F. F. Jian, X. Wang. Thin Solid Films 517, 652 (2008).

97. S. Yagi, T. Nakagawa, E. Matsubara, S. Matsubara, S. Ogawa, H. Tani. Electrochem. Solid-State Lett. 11, E25 (2008).

98. Q. Fan, M. S. Whittingham. Electrochem. Solid-State Lett. 10, A48 (2007).

99. H. W. Lu, D. Li, K. Sun, Y. S. Li, Z. W. Fu. Solid State Sci. 11, 982 (2009).

100. C. M. Ban, N. A. Chernova, M. S. Whittingham. Electrochem. Commun. 11, 522 (2009).

101. Y. X. Gu, F. F. Jian. J. Phys. Chem. C 112, 20176 (2008).

102. H. W. Lu, L. Yu, W. Zeng, Y. S. Li, Z. W. Fu. Electrochem. Solid-State Lett. 11, A140 (2008).

103. Y. X. Gu, D. R. Chen, X. L. Jiao, F. F. Liu. J. Mater. Chem. 16, 4361 (2006).

104. Y. X. Gu, D. R. Chen, M. L. Jiao. J. Phys. Chem. B 109, 17901 (2005).

105. C. L. Shao, N. Yu, Y. C. Liu, R. X. Mu. J. Phys. Chem. Solids 67, 1423 (2006).

106. N. Yu, C. L. Shao, Y. C. Liu, H. Y. Guan, X. H. Yang. J. Colloid Interface Sci. 285, 163 (2005).

107. J. C. Kuo, S. C. Lee, K. C. Hsu, S. J. Lw, B. Y. Chou, Y. S. Fu. Mater. Lett. 62, 4594 (2008).

108. Y. H. Ding, P. Zhang, Z. L. Long, Y. Jiang, D. S. Gao. J. Alloys Compd. 462, 340 (2008).

109. C. R. Yang, Z. D. Jia, Z. C. Guan, L. M. Wang. J. Power Sources 189, 716 (2009).

110. A. I. Gopalan, K. P. Lee, K. M. Manesh, P. Santhosh. J. Membr. Sci. 318, 422 (2008).

111. X. Li, G. Cheruvally, J. K. Kim, J. W. Choi, J. H. Ahn, K. W. Kim, H. J. Ahn. J. Power Sources 167, 491 (2007).

112. P. Raghavan, X. H. Zhao, J. K. Kim, J. Manuel, G. S. Chauhan, J. H. Ahn, C. Nah. Electrochim. Acta 54, 228 (2008).

113. P. Raghavan, J. W. Choi, J. H. Ahn, G. Cheruvally, G. S. Chauhan, H. J. Ahn, C. Nah. J. Power Sources 184, 437 (2008).

114. L. Zhao, H. Zhang, X. R. Li, J. Zhao, C. Zhao, X. Y. Yuan. J. Appl. Polym. Sci. 111, 3104 (2009).

115. J. K. Kim, G. Cheruvally, X. Li, J. H. Ahn, K. W. Kim, H. J. Ahn. J. Power Sources 178, 815 (2008). 
116. A. I. Gopalan, P. Santhosh, K. M. Manesh, J. H. Nho, S. H. Kim, C. G. Hwang, K. P. Lee. J. Membr. Sci. 325, 683 (2008).

117. S. S. Choi, Y. S. Lee, C. W. Joo, S. G. Lee, J. K. Park, K. S. Han. Electrochim. Acta 50, 339 (2004).

118. S. W. Choi, S. M. Jo, W. S. Lee, Y. R. Kim. Adv. Mater. 15, 2027 (2003).

119. S. W. Choi, J. R. Kim, Y. R. Ahn, S. M. Jo, E. J. Cairns. Chem. Mater. 19, 104 (2007).

120. K. Gao, X. Hu, C. Dai, T. Yi. Mater. Sci. Eng.: B 131, 100 (2006).

121. J. K. Kim, G. Cheruvally, J. W. Choi, J. H. Ahn, D. S. Choi, C. E. Song. J. Electrochem. Soc. 154, A839 (2007).

122. J. R. Kim, S. W. Choi, S. M. Jo, W. S. Lee, B. C. Kim. Electrochim. Acta 50, 69 (2004).

123. J. R. Kim, S. W. Choi, S. M. Jo, W. S. Lee, B. C. Kim. J. Electrochem. Soc. 152, A295 (2005).

124. S. W. Lee, S. W. Choi, S. M. Jo, B. D. Chin, D. Y. Kim, K. Y. Lee. J. Power Sources 163, 41 (2006).

125. H. Na, Y. Zhao, C. Zhao, X. Yuan. Polym. Eng. Sci. 48, 934 (2008).

126. Q. Z. Xiao, Z. H. Li, D. S. Gao, H. L. Zhang. J. Membr. Sci. 326, 260 (2009).

127. T. H. Cho, M. Tanaka, H. Onishi, Y. Kondo, T. Nakamura, H. Yamazaki, S. Tanase, T. Sakai. J. Power Sources 181, 155 (2008).

128. S. Choi, J. Kim, S. Jo, W. Lee, Y. Kim. J. Electrochem. Soc. 152, A989 (2005).

129. H. R. Jung, D. H. Ju, W. J. Lee, X. W. Zhang, R. Kotek. Electrochim. Acta 54, 3630 (2009).

130. G. C. Li, Z. Li, P. Zhang, H. Zhang, Y. Wu. Pure Appl. Chem. 80, 2553 (2008).

131. C. Kim. J. Power Sources 142, 382 (2005).

132. C. Kim, J. S. Kim, S. J. Kim, W. J. Lee, K. S. Yang. J. Electrochem. Soc. 151, A769 (2004).

133. J. S. Im, S. W. Woo, M. J. Jung, Y. S. Lee. J. Colloid Interface Sci. 327, 115 (2008).

134. S. J. Park, S. H. Im. Bull. Korean Chem. Soc. 29, 777 (2008).

135. H. D. Nguyen, J. M. Ko, H. J. Kim, S. K. Kim, S. H. Cho, J. D. Nam, J. Y. Lee. J. Nanosci. Nanotechnol. 8, 4718 (2008).

136. S. Chalk, J. Miller. J. Power Sources 159, 73 (2006).

137. L. Wang, R. Yang. Energy Environ. Sci. 1, 268 (2008).

138. J. S. Im, S. J. Park, T. J. Kim, Y. H. Kim, Y. S. Lee. J. Colloid Interface Sci. 318, 42 (2008).

139. R. Yang, Y. Wang. J. Am. Chem. Soc. 131, 4224 (2009).

140. J. S. Im, O. Kwon, Y. H. Kim, S. J. Park, Y. S. Lee. Microporous Mesoporous Mater. 115, 514 (2008).

141. D. Kim, S. Park, B. Kim, B. Chin, S. Jo, D. Kim. Macromol. Res. 13, 521 (2005).

142. C. Wang. Chem. Rev. 104, 4727 (2004).

143. Z. Shao, S. Haile. Nature 431, 170 (2004).

144. J. Kim, H. Jia, P. Wang. Biotechnol. Adv. 24, 296 (2006).

145. H. Liu, C. Song, L. Zhang, J. Zhang, H. Wang, D. Wilkinson. J. Power Sources 155, 95 (2006).

146. R. Bashyam, P. Zelenay. Nature 443, 63 (2006).

147. J. Kim, H. F. Jia, P. Wang. Biotechnol. Adv. 24, 296 (2006). 